\title{
EMERGENCY APPROPRIATIONS AND THE Fiscal Response to September 11
}

\section{By George L. Ward}

Abstract: One of the prominent features of the Budget Enforcement Act of 1990 (BEA) is the provision for emergency spending. Since the implementation of the BEA, emergency supplemental appropriations have been granted in a variety of situations, from droughts to wars and earthquakes to riots. Most recently, appropriations were made available in response to the September 11 terrorist attacks on the United States. This article describes the emergency appropriations process following the attacks. Additionally, proposed alternatives to the current appropriations process are presented and assessed in light of the events of September 11.

The terrorist attacks of September 11, 2001, brought unprecedented destruction to the United States. More than 3,000 lives were lost and billions of dollars worth of damage occurred. Three days after the attacks, Congress introduced legislation that provided 40 billion dollars to federal agencies and affected communities for relief and counter-terrorism efforts. This legislation represented one of the first official acts of response to the attacks and helped open the way for the nation to heal.

On occasion, unforeseen events occur, such as the September 11 attacks, that the traditional federal budget process is not suited to handle. The current budget process, which can take 18 months or longer from the time a need is identified to the moment funds are made available, has an inadequate time frame for effectively responding to sudden emergencies. Events such as earthquakes, floods, wars, and terrorist attacks require immediate funding to mitigate damage, protect lives and property, and prevent further losses. Accordingly, Congress established procedures outlined in the Budget Enforcement Act of 1990 (BEA) that give Congress and the president authority to designate emergency funds when deemed necessary.

This article provides a review of the emergency appropriations process as outlined in the Budget Enforcement Act, including examples of when and how emergency appropriations have been implemented during the past decade. Additionally, it will describe the most recent case involving emergency appropriations, which emerged in response to the terrorist attacks of September 11. In conclusion, alternatives to the current emergency appropriations process will be presented, and the merits of each will be assessed in light of the emergency appropriation following the September 11 attacks.

\section{The Emergency Appropriations Process}

\section{Emergencies and the Budget Enforcement Act}

Prior to the Budget Enforcement Act of 1990, Congress and the president had few limitations to appropriating supplemental funds when emergencies occurred. Discretionary funds were often tapped when a need arose for additional monies to spend on events that could only qualify as an emergency under the most liberal definition of that word. The Budget and Impoundment Control Act of 1974 was an early attempt at curbing emergency spending:

The 1974 Act required that the totals in both the President's budget request and the Congressional budget resolution reflect an allowance for contingencies and 'unanticipated uncontrollable expenditures' for the upcoming fiscal year-that is, amounts that might later need to be provided through supplementals (CBO, 2001, 2).

George Ward is a Master of Public Administration degree candidate at The George Washington University. Mr. Ward is currently a Presidential Management Intern at the U.S. Department of State. He received a bachelor s degree in Economics from Brigham Young University and a Master s degree in Economics from the University of Delaware. 


\section{EMERGENCY APPROPRIATIONS AND THE FISCAL RESPONSE TO SEPTEMBER 11}

Fiscal restraint was often lacking when emergency supplemental appropriations were enacted prior to 1990. Congress recognized this and sought to decrease emergency appropriations. The definition of an emergency was restricted through amendments to the Balanced Budget and Emergency Deficit Control Act of 1985 (GAO, 1999). However, these restrictions were not honored in the emergency appropriations process until the implementation of the Budget Enforcement Act of 1990.

One negative effect of the BEA, according to James Thurber, was the reduced "flexibility of fiscal policy in cases of emergencies or changing national or international situations" $(1997,67)$. However, "the law provided for exemptions to spending ceilings due to 'emergency needs," and in the case of the Persian Gulf War, "expenditures were designated as an "emergency need' and [were] not counted against the defense spending ceiling" (67). Exemptions to spending ceilings in the BEA brought about a significant change in addressing emergency appropriations.

Wetterau described the spending caps as follows:

BEA set adjustable deficit targets that allowed for unexpected economic changes and unforeseen rises in entitlement program costs. For fiscal 1991 to 1993, BEA imposed separate spending caps for defense, domestic, and international programs. Funds are automatically sequestered if spending exceeds one of these caps, but cuts are limited to only those programs within the cap. The president can authorize spending above the cap in times of war or disaster without triggering automatic cuts $(1998,231)$.

The process described by Wetterau was designed to aid Congress in reducing the deficit, which, by 1990 , would be "virtually impossible" without some modifications (230).

Schick notes that the BEA has had a significant effect on supplemental appropriations. He observes:

The number and size of supplemental appropriations have decreased during the past decade, principally because of constraints imposed by Gramm-Rudman-Hollings and the Budget Enforcement Act. By the time Congress takes up supplementals, virtually all funds available within the BEA caps have been spoken for $(1995,130)$.

The BEA provides that spending caps can only be exceeded if Congress and the president justify an appropriation for an event that qualifies as an emergency. According to Schick, Congress "has been reluctant to [exceed spending caps] except in crises" (130). Schick goes on to state that the "strict budget limitations" of the Budget Enforcement Act have reduced "the temptation to [enhance] supplementals with a great many appropriations," which was commonly the case under supplemental appropriation legislation prior to 1990 (130).

Despite the spending caps, the BEA leaves room for interpretation regarding the definition of an emergency. In 1998, the Congressional Budget Office (CBO) stated that an 'emergency' is not clearly defined in budget process law. "Under procedures that have been in effect since 1991, emergency spending is generally whatever the Congress and the president deem it to be" (CBO, $1998,1)$. In other words, if the president and Congress agree that an emergency exists, funding will be made available. Even so, the BEA has brought about some degree of restriction to the emergency appropriations process.

There are a limited number of methods federal agencies may use to receive funding through emergency appropriations. According to the General Accounting Office (GAO), "first, agencies may receive funding as part of their regular appropriation" $(1996,6)$. Many funds used in disasters or crises are allocated through the traditional appropriations process. The Federal Emergency Management Agency (FEMA) is the most obvious example of an agency that receives funding through this process. FEMA's role is to provide disaster and other emergency relief and, as the federal government's chief emergency responder, FEMA receives a designated appropriation each year.

The second way emergency funds are made available to agencies is through contingent emergency appropriations, which GAO defines as "funds which are designated by the Congress as emergency funds but whose use is contingent on a Presidential designation of an emergency" (GAO, 1999, 6). Once the president designates these funds, there is little difference between contingent emergency appropriations and emergency supplemental appropriations. Accordingly, as soon as 
Congress and the president have officially designated the contingent emergency appropriations, $\mathrm{CBO}$ places them in the same category as standard emergency appropriations (CBO, 1998).

The third way agencies receive funding for emergencies, which is the focus of this article, is through supplemental appropriations. Supplemental appropriations are discretionary funds provided by legislation that are made available for emergency or crisis situations. Throughout the 1990s, the majority of emergency funds were appropriated through this mechanism.

\section{Types of Emergency Appropriations}

Schick defines an emergency appropriation as "an appropriation that the president and Congress have designated as an emergency. An emergency appropriation causes an increase in the relevant discretionary spending limits to accommodate the additional spending" $(1995,210)$. The Office of Management and Budget (OMB) established guidelines in 1991 to identify the conditions that give rise to emergency funding under the terms of the BEA. The five guidelines are as follows:

1. Necessary expenditure - an essential or vital expenditure, not one that is merely useful or beneficial;

2. Sudden-quickly coming into being, not building up over time;

3. Urgent - a pressing and compelling need requiring immediate action;

4. Unforeseen-not predictable or anticipated as a coming need; and

5. Not permanent - the need is temporary (CBO, 1998, 15).

Since 1990, emergency supplemental appropriations have been granted in a variety of contexts which typically fall into five categories: war/military operations, humanitarian assistance, natural disasters, terrorist incidents, and domestic disturbances. Some of the notable events that have received emergency appropriations since 1991 are listed in Table 1.

The majority of events that received emergency supplemental appropriations during this time were natural disasters, since many natural disasters fit each of the five criteria identified by OMB. However, not all emergency supplemental appropriations fall into one of these categories or meet OMB criteria. Meyers describes how Congress soon developed a tendency to broadly interpret emergencies as required in the BEA:

Emergencies differ in the eyes of various beholders, of course, and 1991 featured a variety of attempts to classify spending proposals as responding to emergencies. For example, a supplemental appropriation bill for the war against Iraq included emergency subsidy increases for GI Bill education benefits and life insurance $(1994,23)$.

The BEA was designed to avert the practice of designating a non-emergency event as an emergency in order to secure otherwise unavailable funding for a particular program. However, Congress continues to circumvent regulations in order to expand its spending capabilities, as the GI Bill subsidy increase example suggests.

\section{Origination of Emergency Appropriations}

Some aspects of the emergency appropriations process are different from the traditional budget process. First, emergency supplemental appropriations can be originated by either Congress or the president but must be authorized by both. Of the three methods by which appropriations can be made for emergency purposes, emergency funding through regular appropriations is primarily a practice of Congress. Between 1991 and 1999, Congress originated more than 22 billion dollars in emergency funds through the regular appropriations process, while the president originated approximately 7.5 billion dollars. The CBO reported that during the

TABLE 1: Major events that received emergency appropriations, 1991-2001

\begin{tabular}{|l|l|}
\hline Year & Event \\
\hline 1991 & $\begin{array}{l}\text { Operations Desert Shield \& } \\
\text { Desert Storm }\end{array}$ \\
\hline 1992 & Los Angeles riots \\
\hline 1993 & Midwest flooding \\
\hline 1994 & Los Angeles earthquake \\
\hline 1997 & Bosnia, natural disasters \\
\hline 1999 & Kosovo, Hurricane Mitch \\
\hline 2001 & September 11 terrorist attacks \\
\hline
\end{tabular}


1990s, 34 laws containing supplemental appropriations or rescissions totaling nearly 138 billion dollars were enacted (CBO, 2001, 6). Figure 1 offers a comparison of emergency appropriations originated by the Congress and the president between 1991 and 1999.

\section{FIGURE 1: Emergency Funding Origination, 1991-1999}

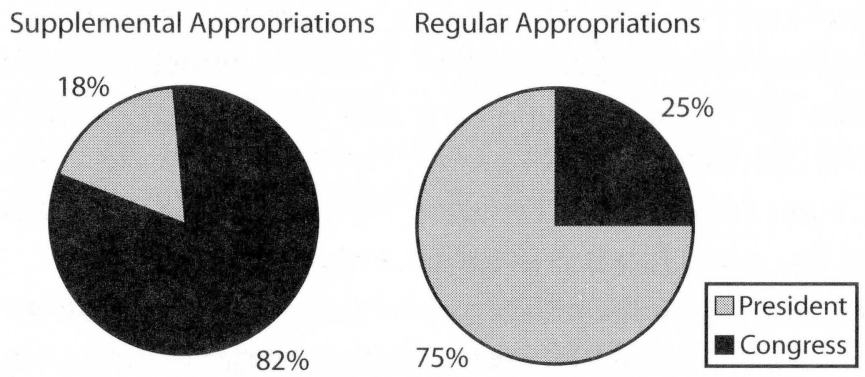

Source: $C B O, 1998,23-24$

A second distinguishing feature of the supplemental process was identified in a recent $\mathrm{CBO}$ report:

Unlike regular appropriation bills, which are under the jurisdiction of a single appropriations subcommittee in the House and the Senate, supplementals may include items under the jurisdiction of many subcommittees, with varying purposes and levels of urgency. In considering supplementals, appropriators must grapple with issues of grouping disparate items, considering emergency and nonemergency items together, and determining when requests form enough of a "critical mass" to warrant going forward with a supplemental appropriation bill (CBO, 2001, 7).

In some cases, particularly where there is disagreement about the classification of an emergency, this aspect of the supplemental process may be a significant hindrance to releasing supplemental funds. However, there was no doubt that the events of September 11 constituted an emergency and, as the next section describes, Congress and the president responded effectively.

\section{Emergency Appropriations Relating to the September 11 Terrorist Attacks}

\section{Emergency Supplemental Appropriations Process}

On September 11, 2001, terrorists hijacked four U.S. commercial airliners. The terrorists crashed two airplanes into both towers of the World Trade Center in New York City, which completely destroyed the structures. A third airplane struck the Pentagon in Arlington, Virginia, and the fourth crashed into a remote area in western Pennsylvania. In approximately two hours, more than 3,000 people were killed, smoke and debris engulfed Manhattan's financial district, and the country faced months of recovery and uncertainty.

Congress and the president reacted swiftly to the crisis. On the morning of September 14, 2001, Representative C.W. "Bill" Young (R-Florida) introduced the 2001 Emergency Supplemental Appropriations Act for Recovery from and Response to Terrorist Attacks on the United States (H.R. 2888) in the U.S. House of Representatives. By early afternoon, the legislation was passed in the House by a $422-0$ vote and was passed in the Senate soon after. The bill was immediately cleared for the White House and presented to the president by the end of the day. On September 18, the president signed the bill and it became Public Law 107-38. The particularly short timeframe in which this emergency supplemental legislation was enacted was one of several unusual features.

The fact that Congress made the funds available before agencies submitted their requests was also unusual. In most other appropriations processes, agencies initially request funding from Congress, which in turn authorizes emergency funds to be made available. In the case of September 11, Congress immediately recognized the need for emergency appropriations and authorized the release of 40 billion dollars to agencies. Because of the unique circumstances, Congress gave $\mathrm{OMB}$ the responsibility of reviewing agencies' requests for funding and making appropriations available to meet obligations. Congress, however, did retain some oversight of the appropriations process by stipulating that ten billion dollars of the total appropriation "shall not be made available for transfer to any Department or Agency until 15 days after the Director of the Office 
of Management and Budget has submitted to the House and Senate committees on appropriations a proposed allocation and plan for use of the funds for that Department or Agency" (Public Law 107-83).

Despite this oversight, Congress gave broad application authority to agencies. Congress stipulated that the funds could be applied to any of the following activities:

1. Providing federal, state, and local preparedness for mitigating and responding to the attacks;

2. Providing support to counter, investigate, or prosecute domestic or international terrorism;

3. Providing increased transportation security;

4. Repairing public facilities and transportation systems damaged by the attacks; and

5. Supporting national security (Public Law 107-83).

The significant degree of appropriation authority granted to the president was also out of the ordinary. Congress authorized the funds before the president had even formally made the request for funds-the equivalent of handing the president a blank check.

Not surprisingly, while Congress authorized and the president approved 40 billion dollars for federal agencies' needs following the September 11 attacks, agencies submitted more than 120 billion dollars in requests by mid-October - three times the amount Congress authorized (Caruso and Rovner, 2001). Several factors account for the large number of requests accompanying this emergency supplemental appropriation: (1) the atmosphere of anxiety and fear following the attacks; (2) the broadly-defined categories identified by Congress opened the door for more requests than may have otherwise been made under more stringent definitions; (3) agencies may have assumed that more funding would be made available by Congress once the disaster's full impact was realized; and (4) the unprecedented situation may have invited less restraint in appropriation requests. In addition, some agencies may have simply used the emergency appropriation as an opportunity to secure funds that they were either requesting in FY 2002 or had requested previously without success.

To meet the immediate needs of agencies in emergency situations, many of the practices of the traditional budget process were set aside. As a result, the valuable feedback mechanisms within an agency and those between $\mathrm{OMB}$ and agency budget officers were minimized. In one agency, bureaus were given only one day to determine their needs and submit a request for funds.

The enactment of the appropriations bill on September 18 authorized $\mathrm{OMB}$ to begin releasing funds to federal agencies. By the end of the month, OMB released the first 5.1 billion dollars to the only two federal agencies that experienced direct losses as a result of the attacks - the Department of Defense, which suffered damage to its headquarters, and the Treasury, which had offices for 1,000 of its employees in the World Trade Center (Budget and Program Newsletter, 2001). Most of the initial funds provided disaster relief and recovery and increased security activities. The Defense Department and FEMA received the largest allotments. These and the other large initial emergency allocations are identified in Table 2.

The allocation of funds after September 11 followed a pattern of emergency spending evident since the enactment of the BEA. Total emergency appropriations (in terms of budget authority) across the federal

\section{TABLE 2: Initial allocations in the 2001 emergency appropriation resulting from the September 11 terrorist attacks}

\begin{tabular}{|c|c|c|}
\hline Agency & $\begin{array}{l}\text { Amount } \\
\text { (in millions) }\end{array}$ & Activity \\
\hline Defense Department & $\$ 2,500$ & $\begin{array}{l}\text { Enhanced intelligence and } \\
\text { military readiness, repairing } \\
\text { Pentagon }\end{array}$ \\
\hline FEMA & $\$ 2,000$ & $\begin{array}{l}\text { Emergency aid and disaster } \\
\text { relief efforts }\end{array}$ \\
\hline $\begin{array}{l}\text { Department of } \\
\text { Transportation }\end{array}$ & $\$ 141$ & $\begin{array}{l}\text { Enhanced airport security and } \\
\text { law enforcement }\end{array}$ \\
\hline Health and Human Services & $\$ 120$ & Medical Needs \\
\hline $\begin{array}{l}\text { Small Business } \\
\text { Administration }\end{array}$ & $\$ 100$ & Disaster loans \\
\hline State Department & $\$ 49$ & $\begin{array}{l}\text { Rewards for the apprehension } \\
\text { of terrorists, emergency } \\
\text { preparedness }\end{array}$ \\
\hline Treasury Department & $\$ 48$ & $\begin{array}{l}\text { Relocation of employees from } \\
\text { the World Trade Center, } \\
\text { tracking terrorist funds }\end{array}$ \\
\hline Justice Department & $\$ 41$ & $\begin{array}{l}\text { FBI, U.S. Marshals Service } \\
\text { investigation and security } \\
\text { activities }\end{array}$ \\
\hline Labor Department & $\$ 20$ & $\begin{array}{l}\text { Employment initiatives, health } \\
\text { and safety monitoring at } \\
\text { disaster sites }\end{array}$ \\
\hline $\begin{array}{l}\text { General Services } \\
\text { Administration }\end{array}$ & $\$ 9$ & $\begin{array}{l}\text { Increased security of federal } \\
\text { buildings }\end{array}$ \\
\hline Energy Department & $\$ 5$ & $\begin{array}{l}\text { Increased security of national } \\
\text { laboratories }\end{array}$ \\
\hline
\end{tabular}

Source: Government Executive 2001; Budget and Program Newsletter 2001, 2 


\section{EMERGENCY APPROPRIATIONS AND THE FISCAL RESPONSE TO SEPTEMBER 11}

government from 1991 to 1999 exceeded 150 billion dollars. The Defense Department, FEMA, and the Department of Agriculture received the bulk of emergency funds during this period. Actual emergency funds spent by the Defense Department and FEMA between 1991 and 1999 were 70.2 billion dollars and 22.3 billion dollars, respectively (CBO, 1998). As with the initial September 11 allocation, the Defense Department received nearly fifty percent of emergency appropriations during the 1990s. As more of the 40 billion-dollar appropriation was released, it became clear that the Defense Department would be the primary beneficiary of the legislation.

Congress and the president divided authority over the 40 billion dollars (each was responsible for 20 billion dollars). Funding requirements within the bill specified that "not less than one-half of the 40 billion [dollars] shall be for disaster recovery activities and assistance related to such terrorist acts in New York, Virginia, and Pennsylvania" (Public Law 107-38). Despite the relatively swift release of funds through this process, criticism was directed at $\mathrm{OMB}$ concerning the areas that remained unfunded-particularly money that was earmarked for New York City (which was promised 20 billion dollars but only received approximately 10 billion dollars by year's end) (Caruso, 2001).

By December 2001, OMB had released nearly 20 billion dollars of the emergency appropriation. The remaining 20 billion dollars was attached to the Defense Department's appropriation bill for FY 2002, titled Making appropriations for the Department of Defense for the fiscal year ending September 30, 2002, and for other purposes. The "other purposes" included numerous September 11 related initiatives and programs from many federal agencies. Homeland security initiatives received 8.3 billion dollars of the final allocation and an equal amount went to continuing recovery efforts in affected areas (1).

The final picture of the emergency appropriation showed a significant focus on defense spending. In the end, the Defense Department received the bulk of the original 40 billion dollars in emergency funds (amounting to 17.2 billion dollars). Areas affected by the attacks, including New York, received 11.1 billion dollars, while homeland security initiatives received 9.9 billion dollars (1).

\section{Alternative Approaches to Emergency Appropriations}

Despite the the improvements incorporated in the Budget Enforcement Act, the present emergency appropriations process has not escaped criticism. The following offers two alternative approaches to the emergency appropriations process-"rainy day" funds and competitive emergency appropriations.

Most states have established the equivalent of a rainy day fund-surplus revenues set aside for emergency purposes-because of constraints on their access to emergency funds. Specifically, as a 1999 GAO report revealed, "a primary rationale for establishing reserves at the state level is the real constraints imposed by balanced budget requirements and the credit markets" $(1999,29)$.

While the federal government is not as constrained as are many state governments, it could benefit from adopting state governments' practice of reserving emergency funds, which could bring "greater transparency in the budget process" (GAO, 1999, 23). Additionally, the use of emergency funds among federal agencies "may reduce the need for supplemental appropriations" and provide "easier access to funding to respond to emergencies more quickly" (GAO, 1999, 23).

CBO identified two additional benefits of establishing emergency reserve funds:

One advantage . . . is that it might highlight overall emergency needs more effectively and enable policymakers to draw a more direct connection between emergency spending and any offsets used to pay for that spending. An emergency reserve fund could also be used to encourage efforts to avoid or mitigate disasters as well as to highlight potential alternatives to federal action, such as state or local initiatives or private insurance $(1998,17)$.

The process of establishing emergency reserves can influence policymakers to think about emergencies more consistently, and may even encourage them to develop measures to prevent disasters.

Another alternative to the current appropriations process is competitive emergency appropriations, which would revoke the exemption for emergencies outlined 
in the BEA. Under this alternative, emergency supplementals would receive no preferential treatment but would instead be required to compete with other supplemental appropriations from the discretionary spending reserves and would be "offset with spending cuts" (CBO, 1998, 14).

A problem with the competitive appropriations process is revealed when considering the sequence of events after September 11 . The initial attack, which caused significant damage to infrastructure as well as significant loss of life, created the first costs. In response, 40 billion dollars was immediately allocated. This was before the additional costs of significant military operations against the Taliban regime in Afghanistan were fully realized. The second set of costs came as military operations began in early October. A third set of costs came as anthrax attacks were discovered at mail-handling facilities and government buildings, which required mail-handling enhancements, antibiotic production, and disinfection of affected facilities. The impact of each of these events on the budget was unpredictable. An emergency appropriations mechanism based on competitive and limited appropriations would likely be incapable of handling a series of costly events such as these. Similarly, under the emergency reserves alternative, it is highly unlikely that Congress could have been prepared to meet the need for funds necessary to start the recovery process after September 11 .

The shift in priorities within agencies caused by the dramatic impact of the terrorist attacks is an important consideration when weighing alternative approaches to emergency appropriations. Under both alternativesthe rainy day fund and the competitive appropriations process-many of the current programs and services offered by the government would cease as funds would be channeled towards security, defense, disaster relief, and counter-terrorism activities. The likely commensurate shift in personnel allocations as jobs follow the funding would be highly disruptive. However, an advantage of both alternatives is that the federal budget process would be better prepared to deal with changing needs and priorities.
Referring to recent events that have received emergency supplemental funding, $\mathrm{CBO}$ observed:

What these events have in common is a degree of unpredictability. Disasters and other emergency situations can entail sudden and unexpected demands for high levels of funding. In the case of peacekeeping efforts in Bosnia or the computer conversion in anticipation of the year 2000, which both received emergency funding for 1999, the length and magnitude of the commitment can be difficult to determine in advance $(1998,1)$.

The September 11 appropriations case makes this observation even more poignant. A competitive appropriations process would be of limited value when such catastrophic events occur-the very purpose for which emergency appropriations were designed.

climate, the present
emergency
appropriations
process appears
superior to the
alternatives.

In the current climate, the present emergency appropriations process appears superior to the alternatives. However, there are shortcomings in the current process. Perhaps the most significant was identified by Donahue and Joyce, who describe the current process as one that creates incentives "to fund disaster assistance after the fact, rather than at a point where a disaster might be prevented" (Donahue and Joyce, 2001, 735). This incentive, they write, is caused by the difficulty of securing funds for unforeseen events in the competitive budget process as well as the political appeal of "appear[ing] to be immediately responsive to disasters when they occur" (735). They point out that "in the long run, the current budget rules do not promote the funding of mitigation and prevention activities, which arguably would reduce the need for future disaster funding" (735). Though the current process may effectively provide the necessary response and recovery resources for disasters after the fact, it is inherently short-sighted in terms of its ability to develop a strategic response to long-term prevention.

\section{Conclusion}

The emergency appropriations process in federal budgeting has long provided Congress and the president with a relatively effective means to respond to unexpected disasters, emergencies, and related events. 


\section{EMERCENCY APPROPRIATIONS AND THE FISCAL}

Although the process has occasionally been abused, the Budget Enforcement Act of 1990 sought to provide a means whereby Congress and the president could appropriate funds that were not subject to spending limits in times of emergency. The tragic attacks of September 11, 2001, are the most recent events that warranted the provision of emergency supplemental appropriations and provided an opportunity to assess the emergency appropriations process. While these attacks were unprecedented, the corresponding emergency appropriations process is useful and the current process provided through the BEA of 1990 appears to be sufficient for responding to crises such as September 11. However, the current process provides negative incentives to lawmakers by discouraging a proactive approach to emergency funding. Accordingly, the current budget process may stand to benefit from further reform.

\section{References}

Budget and Program Newsletter, Vol. 27, No, 38. Washington, DC, September 28, 2001.

Caruso, Lisa. Disagreement over supplemental stymies defense spending bill. Government Executive Magazine. Washington, DC, November 6, 2001. www.govexec.com/news.

Caruso, Lisa. Pressure grows for more emergency spending. Government Executive Magazine. Washington, DC, November 2, 2001. www.govexec.com/news.

Caruso, Lisa. House, Senate conferees wrap up final two spending bills. Government Executive Magazine. Washington, DC, December 19, 2001. www.govexec.com/news.

Caruso, Lisa and Julie Rovner. Budget Director asks return to fiscal discipline. Government Executive Magazine. Washington, DC, October 11, 2001. www.govexec.com/news.

Congressional Budget Office. Emergency Spending Under the Budget Enforcement Act. Washington, DC: CBO, December 1998.

Congressional Budget Office. Supplemental Appropriations in the 1990s. Washington, DC: CBO, March 2001.
Donahue, Amy K. and Philip G. Joyce. A framework for analyzing emergency management with an application to federal budgeting. Public Administration Review, Vol. 61, No. 6., November/December 2001.

Government Executive Magazine. Breakdown of $\$ 5.1$ billion. Washington, DC, September 24, 2001. www.govexec.com/news.

Meyers, Roy T. Strategic Budgeting. University of Michigan Press, 1994.

Office of Management and Budget. "President Bush announces $\$ 9.3$ billion in emergency funds." News Release 2001-59. Washington, DC: Office of Management and Budget, November 9, 2001.

Public Law 107-38. 2001 Emergency Supplemental Appropriations Act for Recovery from and Response to Terrorist Attacks on the United States. Washington, DC: $107^{\text {th }}$ Congress, 2001.

Schick, Allen. The federal budget: Politics, policy, process. Washington, DC: The Brookings Institution, 1995.

Thurber, James A. Congressional budget reform: Impact on the appropriations committees, Public Budgeting \& Finance, Fall 1997.

U.S. General Accounting Office. Budgeting for emergencies: State practices and federal implications (GAO/AIMD-99-250). Washington, DC: GAO, September 1999.

Wetterau, Bruce. Congressional Quarterly s desk reference on the federal budget. Washington, DC: Congressional Quarterly Inc., 1998. 